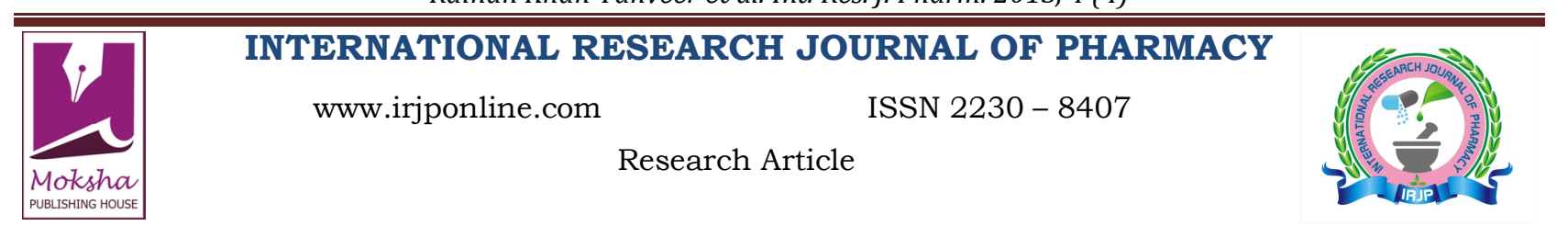

\title{
EVALUATION OF CYTOTOXIC AND ANTHELMINTIC ACTIVITIES OF BARK EXTRACT OF APHANAMIXIS POLYSTACHYA (WALL.)
}

Raihan Khan Tanveer ${ }^{1}$, Karmakar Palash ${ }^{1 *}$, Das Abhijit, Banik Rana ${ }^{1}$, Sattar Mohammad Mafruhi ${ }^{2}$

${ }^{1}$ Department of Pharmacy, Noakhali Science and Technology University, Sonapur, Noakhali-3814, Bangladesh

${ }^{2}$ Department of Pharmacy, Jahangirnagar University, Savar, Dhaka-1342, Bangladesh

Email: pknstu@gmail.com

Article Received on: 18/02/13 Revised on: 01/03/13 Approved for publication: 11/04/13

DOI: 10.7897/2230-8407.04424

IRJP is an official publication of Moksha Publishing House. Website: www.mokshaph.com

(C) All rights reserved.

\begin{abstract}
Aphanamixis polystachya (Wall.) belongs to the family Meliaceae and it is extensively used in folkloric medicine of Bangladesh, for the treatment of various disorders. This evaluating study of methanolic extract of Aphanamixis polystachya bark was conducted to investigate the cytotoxicity, using brine shrimp lethality as test method as well as anthelmintic activity with the determination of time of paralysis and death using earthworm (Pheritima posthuma) at four different concentrations. The study confirmed that the methanolic extract of the bark of Aphanamixis polystachya possess mild cytotoxic activity $\left(\mathrm{LC}_{50}=26.01 \pm 0.325 \mu \mathrm{g} / \mathrm{ml}\right)$ in comparison to the standard drug vincristine sulphate $\left(\mathrm{LC}_{50}=0.839 \pm 0.013 \mu \mathrm{g} / \mathrm{ml}\right)$. On the other hand methanolic extract showed better anthelmintic activity as it required less time for paralysis and death comparing with the standard drug albendazole (concentration $10 \mathrm{mg} / \mathrm{ml})$. At concentrations $10,20,40$ and $60 \mathrm{mg} / \mathrm{ml}$ methanolic extract showed paralysis at mean time of $35.66 \pm 0.72,32.66 \pm 0.47,27.66 \pm 0.72$ and $25.66 \pm 0.27$ and death at $52.33 \pm 0.72,48.33 \pm 0.47,40.00 \pm 0.98$ and $38.33 \pm 0.27$ minutes, respectively. Whereas the standard drug albendazole showed paralysis and death at $56.20 \pm 0.20$ and $77.40 \pm 0.24$ minutes respectively. Thus, further studies are suggested to isolate the key compounds responsible for the cytotoxic and anthelmintic activities and also to conduct these tests using in vivo procedures.

Key words: Aphanamixis polystachya, bark extract, brine shrimp lethality, anthelmintic activity, Pheretima posthuma.
\end{abstract}

\section{INTRODUCTION}

Drugs obtained from plant origin have always been a subject of interest for the scientists. The study of bioactive compounds from plant sources and extracts are of great importance because the general bioassay detects a wide spectrum of biological activities and a diversity of chemical structures of the particular plant ${ }^{1}$. One fundamental proposition here is that at a higher dose toxicology is simply pharmacology. Thus if toxic compounds are found, a lower non-toxic dose might reveal a useful pharmacological effect concerning on a physiologic system ${ }^{2}$. However, it has been demonstrated that the simple in vivo brine shrimp lethality test might be used as an understandable tool for screening and fractionation of physiologically active plant extract, because of its reasonable correlation with cytotoxic and other biological properties ${ }^{1}$.

Again, heminthes infections are one of the most common and serious infections of both man and animals and also pose a great threat to the public health especially in the countries of third world ${ }^{3}$. Although numerous advances are made regarding the treatment of helminthes infections during the last few decades but still no significant product is developed which can completely control certain helminthes ${ }^{4}$. However, indiscriminate use of several anthelmintics have emerged problems leading to the development of resistance $e^{5,6}$ as well as chemical residue and toxicity problems. ${ }^{7}$. For these reasons, screening of medicinal plants for their anthelmintic activity has become a matter of great scientific interest though synthetic chemicals are extensively used in modern clinical practices worldwide ${ }^{8,9,10}$

As we know the importance of medicinal plants in the treatment of various ailments of human is not new, it started from the beginning of human civilization when people realized that plants not only give us food, shelter and cloths but also give medicine for the survival ${ }^{11,12}$. According to the listing of the World Health Organization (WHO) there are about 21,000 plants which are used for medicinal purposes around the world among which about 150 species are commercially used ${ }^{13,14}$. When screening for biologically active plant constituents it is necessary to select the plant species wisely because the ultimate success of the investigation depends on it. Generally plants used in traditional medicine are more likely to yield pharmacologically active compounds. Thus the study plant is selected considering its local use in traditional medicine.

Aphanamixis polystachya (Wall.) belonging to the family Meliaceae and locally known as Pithraj, an evergreen tree available in many districts of Bangladesh ${ }^{15,16}$. The plant possesses a wide spectrum of phytochemicals like alkaloids, cardiac glycosides, flavonoids, saponins, steroids, tannins, terpenoids etc $^{17}$. Aphanamixis polystachya also has a long history of use in the folkloric medicine in the Asia-pacific region. The bark of the plant is widely used for the treatment of liver and spleen diseases, rheumatism and tumors ${ }^{18,19}$ and also the bark has strong antimicrobial and astringent activities $^{20}$. Beside these heapatoprotective ${ }^{21}$, antifeedant, repellant ${ }^{22}$, cytotoxic ${ }^{23}$, antioxidant and thrombolytic ${ }^{17}$ activity of different parts of the plant are also established. Though there are lots of data in the literature of this plant but as far I know no study was found regarding the investigation of anthelmintic and cytotoxic activities of the bark extract of Aphanamixis polystachya (Wall.) in Bangladesh. Therefore, in the current study we tried to assess the cytotoxic and anthelmintic activity of powdered Aphanamixis polystachya (Wall.) bark extract.

\section{MATERIALS AND METHODS}

Plant Materials

For this study, barks of Aphanamixis polystachya (Wall.) were collected from Khulna region of Bangladesh in June 2012. After collection the taxonomic identification was carried out with the help of taxonomist of Bangladesh National Herbarium, Mirpur, Dhaka, Bangladesh (Accession No. DACB: 37920). 


\section{Chemicals and Reference Drug}

All the chemical reagents used in the analysis of phytochemicals were purchased from Sigma Chemical Co. Ltd (St. Louis, MO, USA) and E. Merck (Germany). For the anthelmintic test, the methanolic extract of barks of Aphanamixis polystachya was tested using different sample concentrations. Distilled water was used as control and Albendazole (Batch no: ALF0170, Square Pharmaceuticals Limited, Bangladesh) was used as the standard drug for evaluation of anthelmintic activity. For the assessment of cytotoxic activity Vincristine Sulphate (VS) was used as standard drug and DMSO was used as control.

\section{Extraction of Plant Materials}

For methanolic extraction $450 \mathrm{~g}$ of air dried powder of barks was immersed in $3000 \mathrm{ml}$ of methanol in a beaker and kept for maceration for 10 days with occasional shaking. At the end of $10^{\text {th }}$ day it was filtered using filter cloth and Whatman ${ }^{\circledR}$ filter paper (Sargent-Welch, USA) and allowed to evaporate. Thus a greenish black colored semisolid mass of the extract was obtained (yield $20 \mathrm{~g}$ ) ${ }^{24}$.

\section{Collection of Worms}

The earthworms, Pheritima posthuma (Annelida) about 3-5 $\mathrm{cm}$ in length and $0.1-0.2 \mathrm{~cm}$ in width and weighing about 0.8-3.04 g were collected from the moist soil of Noakhali Science and Technology University, Sonapur, Noakhali, Bangladesh.

\section{Evaluation of Cytotoxicity}

The cytotoxicity was conducted using brine shrimp lethality test following the method of Saifuzzaman et al. ${ }^{25}$ The brine shrimp eggs were placed in 1 liter of sea water, aerated and hatched for 48 hours at $37{ }^{\circ} \mathrm{C}$ to become nauplii. After 48 hours, ten brine shrimp nauplii were placed in a small container filled with seawater. Methanolic extract of Aphanamixis polystachya bark serially diluted with DMSO (Dimethyl Sulfoxide) was then added to the container. The mortality of brine shrimp was observed after 24 hours of treatment was given. An approximate linear correlation was observed when logarithm of concentration versus percentage of mortality was plotted and the values of $\mathrm{LC}_{50}$ were calculated by probit analysis using SPSS (version 16). Vincristine Sulphate was used as positive control.

\section{Evaluation of Anthelmintic Activity}

The assay for anthelmintic activity was carried out as per the method of Ajaiyeoba et $a l .{ }^{26}$ with insignificant modifications. The test was conducted by using the adult earthworm (Pheretima posthuma) because of its anatomical and physiological similarity with the intestinal round-worm parasite of human beings ${ }^{27,28}$. Earthworms have been used widely for the preliminary evaluation of anthelmintic activity in vitro because of easy availability and ease of use $\mathrm{e}^{29,30}$. All the worms were washed with normal saline water to remove all fecal matters. Extract was weighed and dissolved in $10 \mathrm{ml}$ of distilled water to obtain the concentrations of 10, 20, 40 and $60 \mathrm{mg} / \mathrm{ml}$. Earthworms were divided into six groups (each containing five worms) in petri-dish. The methanolic extract of Aphanamixis polystachya bark was applied to the petri-dishes and the time of paralysis and death was determined. Time for paralysis was noted when no movement of any sort could be observed except when the worms were shaken vigorously. Time for death of worms was recorded after ascertaining that worms neither moved when shaken vigorously nor when dipped in warm water $\left(50^{\circ} \mathrm{C}\right)$ followed by fading away of their body colors.

\section{Statistical Analysis}

Data were processed and analyzed using SPSS (version 16.0). The median lethal concentration $\left(\mathrm{LC}_{50}\right)$ and $95 \%$ confidence intervals (CI) of the test sample was calculated using probit analysis method described by Finney ${ }^{31}$ as the measure of toxicity of the plant. The data of anthelmintic studies were reported as mean \pm standard deviation. For determining the statistical significance, standard error mean and analysis of variance (ANOVA) at $5 \%$ level significance was employed. $\mathrm{P}<0.05$ was considered significant (shown as $*)^{32}$.

Table 1: Cytotoxic potential of methanolic extract of Aphanamixis polystachya barks along with Vincristine Sulphate

\begin{tabular}{|c|c|c|c|c|c|}
\hline \multirow[t]{2}{*}{ Sample } & \multirow[t]{2}{*}{$\mathrm{LC}_{50}(\mu \mathrm{g} / \mathrm{ml})$} & \multicolumn{2}{|c|}{$95 \% \mathrm{CI}$} & \multirow[t]{2}{*}{ Regression Equation } & \multirow[t]{2}{*}{$\mathrm{R}^{2}$} \\
\hline & & Upper limit & Lower limit & & \\
\hline Vincristine Sulphate & $0.839 \pm 0.013$ & 0.871 & 0.807 & $y=34.02 x+52.58$ & 0.952 \\
\hline Methanolic Extract & $26.01 \pm 0.325$ & 26.818 & 25.202 & $y=36.44 x-0.456$ & 0.968 \\
\hline
\end{tabular}

$\mathrm{LC}=$ Lethal concentration, $\mathrm{CI}=$ Confidence Interval, $\mathrm{R}^{2}=$ a statistical measure of how well a regression line approximates real data points

Table 2: Evaluation of anthelmintic activity of methanolic extract of Aphanamixis polystachya bark

\begin{tabular}{|c|c|c|c|}
\hline Test Substance & Concentration (mg/ml) & Time taken for paralysis (min) & Time taken for death (min) \\
\hline Control (Distilled water) & - & - & - \\
\hline Standard (Albendazole) & 10 & $56.20 \pm 0.20$ & $77.40 \pm 0.24$ \\
\hline \multirow{3}{*}{ Methanolic extract } & 10 & $35.66 \pm 0.72^{* *}$ & $52.33 \pm 0.72^{* *}$ \\
\cline { 2 - 4 } & 20 & $32.66 \pm 0.47^{* * *}$ & $48.33 \pm 0.47^{* * *}$ \\
\cline { 2 - 4 } & 40 & $27.66 \pm 0.72^{* * *}$ & $40.00 \pm 0.98^{* * *}$ \\
\cline { 2 - 4 } & 60 & $25.66 \pm 0.27^{* * *}$ & $38.33 \pm 0.27^{* * *}$ \\
\hline
\end{tabular}

Values are expressed as mean \pm standard deviation (SD). Values were found out by using ONE way ANOVA followed by Student's $t$-test. Significance level **P $<0.01, * * * \mathrm{P}<0.001$

\section{RESULTS}

In the present study, methanolic extract showed significant cytotoxic potential demonstrating that the extract is biologically active. The lethal concentration $\left(\mathrm{LC}_{50}\right)$ of the test samples after 24 hours were found by a plot of percentage of the shrimps died in contrast to the logarithm of the sample concentration (toxicant concentration) and the best-fit line was obtained from the curve data by means of regression analysis (table 1). Vincristine Sulphate (VS), which was used as positive control showed $50 \%$ lethality at the concentration of $0.839 \pm 0.013 \mu \mathrm{g} / \mathrm{ml}$. The $\mathrm{LC}_{50}$ values of crude methanolic extract of Aphanamixis polystachya bark was found to be $26.01 \pm 0.325 \mu \mathrm{g} / \mathrm{ml}$. Therefore, the obtained result tends to suggest that methanolic extract of Aphanamixis polystachya may possess mild anticancer activity ${ }^{33}$. 
From the study it was observed that the methanolic extract of Aphanamixis polystachya bark showed not only paralysis but also death of earthworms. It was also evident from the study that the methanolic extract of Aphanamixis polystachya produced significant anthelmintic activity in a dose dependent manner and the activity of the extract was comparable with that of standard drug Albendazole (Table 2). At lowest concentration $(10 \mathrm{mg} / \mathrm{ml})$ the time for paralysis and death of methanolic extract was more than 35 and 52 minutes, respectively which are shown in table 2 . Again, the lowest time for paralysis and death of earthworms (25.66 0.27 and $38.33 \pm 0.27$ minutes respectively) was found at the highest concentration $(60 \mathrm{mg} / \mathrm{ml})$ of the plant extract. Thus it was clear from the present study that with the increasing of concentration the methanolic extract of Aphanamixis polystachya showed better anthelmintic activity.

\section{DISCUSSION}

In the current study both the cytotoxic and anthelmintic tests were performed in vitro. One of the main advantages of analyzing the biological properties of plant extracts in vitro is that the process is cost effective and includes rapid turnover allowing the screening of plants at large scale ${ }^{34}$. Preliminary phytochemical studies on Aphanamixis polystachya confirmed the presence of cardiac glycosides, flavonoids, alkaloids, tannins, terpenoids, steroids, phenols and proteins ${ }^{17}$.

To assess the toxicity of the crude extracts towards the brine shrimp, the brine shrimp lethality bioassay (BSLA) is a routinely and widely used method ${ }^{35}$. This method also indicates the possible toxicity of the extracts on the test materials and several antitumor and pesticidal natural products have been identified using this method ${ }^{36}$. Again, we know that plant extracts contain a higher concentration of bioactive compounds and also several compounds which show cytotoxic activity ${ }^{34}$. It was reported that several active compounds such as anthocyanins, saponins, tannins, flavones and polyphenols etc. are known to be free radical scavenger, reactive species quencher, hydrogen donor, antioxidant, enzymes activator, detoxification inducer, normal cell differentiation promoter, tumor production and proliferation cell inhibitor and apoptosis inducer ${ }^{37,38}$. So, the bioactive compounds of Aphanamixis polystachya may be accountable for the possible cytotoxicity of the methanolic extract of Aphanamixis polystachya bark although the exact mechanism of action and the fundamental phytochemicals responsible for showing these activities are yet to be discovered.

Some of the phyto-constituents like alkaloids, tannins, terpenoids etc. may be accountable to have a significant anthelmintic activity ${ }^{39}$. One study reported that tannins may interfere with energy generation of worms by uncoupling oxidative phosphorylation or they binds to the free protein of the gastrointestinal tract of the worms and lead to death ${ }^{40}$. In another study, alkaloids were shown to cause paralysis of the worms by acting on its central nervous system ${ }^{41}$. The prime effect of albendazole is to cause a flaccid paralysis of the worm which results in expulsion of the worm by peristalsis. Albendazole acts to increase chloride ion conductance of worm muscle membrane which produces hyperpolarization and excitability reduction that leads to muscle relaxation and flaccid paralysis of worms ${ }^{42}$. It is expected that the phytochemicals present in the extract of Aphanamixis polystachya may have produced similar effects causing death of the worms. Therefore, the usual claim of Aphanamixis polystachya bark as an anthelmintic has been confirmed as the extract showed significant activity against Pheritima posthuma.

\section{CONCLUSION}

Plants are abundant of huge phytochemical constituents and many of them are used in different physical ailments. Like other plants, Aphanamixis polystachya also possess several medicinal values. The present study indicates cytotoxic and anthelmintic activities of the bark extract of Aphanamixis polystachya. Considering all of the findings from the present study it can be concluded that Aphanamixis polystachya bark which is traditionally used by the local people of Bangladesh possess varying degree of biological activity. Thus the present study deduces that the plant Aphanamixis polystachya can be a good source of novel anthelmintic and cytotoxic agent. So studies are suggested for the isolation, purification, characterization, and testing of individual compound in vivo.

\section{REFERENCES}

1. Montanher ABP, Pizzolatti MG. An Application of the Brine Shrimp Bioassay for General Screening of Brazilian Medicinal Plants. Acta Farm Bonaerense. 2002; 21(3): 175-8.

2. McLaughlin JL. Crown gall tumors in potato discs and brine shrimp lethality: two simple bioassays for higher plant screening and fractionation. In: Hostettmann K, editor. Methods in Plant Biochemistry. London, Academic Press, 1991; 1-32. PMid:1675250

3. Bundy DA. Immunoepidemiology of intestinal helmintic infection: the global burden of Intestinal Nematod Disease. Trans Royal Soc Trop Med Hyg. 1994; 8: 259-61. http://dx.doi.org/10.1016/00359203(94)90069-8

4. Dama GY, Tare HL, Gore MS, Deore SR, Bidkar JS. Comparative helmintholytic potential of extracts obtained from Cymbopogon citratus and Wrightia tinctoria leaves. International Journal of Pharma and Bio Sciences. 2011; 2(1): 321-7.

5. Iqbal Z, Nadeem QK, Khan MN, Akhtar MS, Waraich FN. In vitro anthelmintic activity of Allium sativum, Zingiber officinale, Cucurbita mexicana, Ficus religiosa. International Journal of Agriculture and Biology. 2001; 3(4): 454-7.

6. Jackson F, Coop RL. The development of anthelmintic resistance in sheep nematodes. Parasitology. 2000; 120: S95-S107. http://dx.doi.org 10.1017/S0031182099005740 PMid: 10874713

7. Akhtar MS, Iqbalb Z, Khanb MN, Lateef M. Anthelmintic activity of medicinal plants with particular reference to their use in animals in the Indo-Pakistan subcontinent. Small Rumin Res. 2000; 38: 99-107. http://dx.doi.org/10.1016/S0921-4488(00)00163-2

8. Githiori JB, Athanasiadou S, Thamsborg SM. Use of plants in novel approaches for control of gastrointestinal helminths in livestock with emphasis on small ruminants. Veterinary Parasitology. 2006; 139(4): 308-20. http://dx.doi.org/10.1016/j.vetpar.2006.04.021 PMid:16725262

9. Jabbar A, Zaman MA, Iqbal Z, Yaseen M, Shamim A. Anthelmintic activity of Chenopodium album (L.) and Caesalpinia crista (L.) against trichostrongylid nematodes of sheep. J Ethnopharmacol. 2007; 114(1): 86-91. http://dx.doi.org/10.1016/j.jep.2007.07.027 PMid:17826017

10. Eguale T, Tadesse D, Giday M. In vitro anthelmintic activity of crude extracts of five medicinal plants against egg-hatching and larval development of Haemonchus contortus. J Ethnopharmacol. 2011; 137(1):108-13.http://dx.doi.org/10.1016/j.jep.2011.04.063 PMid:21605649

11. Alves RRN, Rosa IL. Why study the use of animal products in traditional medicines? J Ethnobiol Ethnomed. 2005; 1: 1-5. http:/ /dx.doi.org/10.1186/1746-4269-1-10PMid:16270913 PMCid:1289291

12. Joseph B, Jini D, Ajisha SU. Phytochemical characterization of herbal drug formulation for arthritis. Research Journal of Phytochemistry. 2012; 6(2):54-60. http://dx.doi.org/10.3923/rjphyto.2012.54.60

13. Zohary D, Hopf M. Domestication of Plants in the Old World. Oxford: Oxford University Press, New York; 2000: p 122.

14. Cefalu WT, Ye J, Wang ZQ. Efficacy of dietary supplementation with botanicals on carbohydrate metabolism in humans. Endocrine Metabolic Immune Disorders- Drug Targets. 2008; 8:78-81. http://dx.doi.org/ 10.2174/ 187153008784534376

15. Sikder MAAS, Kuddus MR, Kaisar MA, Karna S, Rashid MA. In vitro membdrane stabilizing activity, total phenolic content, free radical scavenging and cytotoxic properties of Aphanamixis polystachya (Wall.). Bangladesh Pharmaceutical Journal. 2010; 13(2): 55-9.

16. Ghani A. Medicinal Plants of Bangladesh: Chemical Constituents and Uses. Asiatic Society of Bangladesh. 1998. 
17. Apu AS, Chowdhury FA, Khatun F, Jamaluddin ATM, Pathan AH, Pal A. Phytochemical Screening and In vitro Evaluation of Pharmacological Activities of Aphanamixis polystachya (Wall) Parker Fruit Extracts. Tropical Journal of Pharmaceutical Research. 2013; 12 (1): 111-16.

18. Chopra RN, Nayar SL, Chopra IC. Glossary of Indian Medicinal Plants. New Delhi: CSIR, 1956.

19. Graham JG, Quinn ML, Fabricant DS, Farnsworth NR. Plants used against canceran extension work of Jonathan Hartwell. J Ethnopharmacol.2000; 73: 347-77. http://dx.doi.org/10.1016/S0378$8741(00) 00341-\mathrm{X}$

20. Choudhury R, Choudhury MH, Rashid MA. Antimicrobial activity of Toona ciliata and Amoora rohituka. Fitoter. 2003; 74: 155-58. http://dx.doi.org/10.1016/S0367-326X(02)00322-2

21. Gole MK, Dasgupta S, Sur K, Ghosal J. Heptoprotective effect of Amoora Rohituka. International Journal of Pharmacognosy. 1997; 35(5): 318-22. http://dx.doi.org/10.1080/09251619708951275

22. Talukder FA, Howse PE. Evaluation of Aphanamixis polystachya as a source of repellents, antifeedants, toxicants and protectants in storage against Tribolium castaneum (Herbst). J Stored Prod Res. 1995. 31: 5561. http://dx.doi.org/10.1016/0022-474X(94)00036-S

23. Deshpandey PJ, Gode JD, Prasad GC. Effect of Amoora rohituka on leucocytes in white rats. Journal of Research Medicine. 1964; 2: 512-16.

24. Amole OO, Ilori OO. Antimicrobial activity of the aqueous and ethanolic extracts of the stem bark of alstonia boonei. Int $\mathrm{J}$ Phytopharmacol. 2010; 1(2): 119-23.

25. Saifuzzaman M, Hossain MA, Alam S, Islam MA, Ali ES. Antidiarrheal and cytotoxic activities of Alstonia scholaris bark. International Resarch Journal of Pharmacy. 2013, 4 (3): 101-03.

26. Ajaiyeoba EO, Onocha PA, Olarenwaju OT. In vitro anthelmintic properties of Buchholzia coriaceae and Gynandropsis gynandra extract. PharmBiol.2001;39:217-20.http://dx.doi.org/10.1076/phbi.39.3 .217 .5936

27. Vidyarthi RD. A Text Book of Zoology. 14th Ed. S. Chand and Co, New Delhi; 1967.

28. Chatterjee KD. Parasitology, Protozoology and Helminthology. 6th Ed. In: Guha Ray Sree Saraswaty Press Ltd, Calcutta; 1967.

29. Dash GK, Suresh P, Kar DM, Ganpaty S, Panda SB. Evaluation of Evolvulus alsinoids Linn for anthelmintic and antimicrobial activities. J Nat Rem. 2002; 2:182-85.

30. Shivkar YM, Kumar VL. Anthelmintic activity of latex of Calotropis procera. Pharma Biol. 2003; 41: 263-65. http://dx.doi.org/10.1076 /phbi.41.4.263.15666
31. Finney DJ. Probit analysis. 3rd ed. Cambridge: Cambridge University Press; 1971.

32. Bolton S. Pharmaceutical Statistics: Practical and Clinical Applications.1st ed. New York: MarcelDekker, 1997, 69-78.

33. Prasad GC. Critical care of cases with ayurvedic drugs in the management of cancer. South-East Asian seminar on Herbs and Herbal medicines, Patna; 1999: 16-9.

34. Tiwari P, Kumar B, Kumar M, Kaur M, Debnath J, Pardeep Sharma. Comparative anthelmintic activity of aqueous and ethanolic stem extract of Tinospora cordifolia. Int J Drug Dev \& Res. 2011; 3(1): 70-83.

35. Urmi KF, Masum NHM, Zulfiker AHM, Hossain MK and Hamid K. Comparative Anti-microbial activity and brine shrimp lethality bioassay of different parts of the plant Moringa oleifera lam. Journal of Applied Pharmaceutical Science. 2102; 2 (12): 85-88.

36. Sahgal G, Ramanathan S, Sasidharan S, Mordi MN, Ismail S, Mansor SM. Brine shrimp lethality and acute oral toxicity studies on Swietenia mahagoni (Linn.) Jacq. seed methanolic extract. Pharmacog Res. 2010; 2(4):215-20.http://dx.doi.org/10.4103/0974-8490.69107 PMid:21808570 PMCid:3141130

37. Kumar S, Kumar V, Chandrashekhar MS. Cytotoxic activity of isolated fractions from methanolic extract of Asystasia dalzelliana leaves by brine shrimp lethality bioassay. Int J Pharm Pharm Sci. 2011; 3(3): 13334.

38. Firdaus M, Prihanto AA, Nurdiani R. Antioxidant and cytotoxic activity of Acanthus ilicifolius flower. Asian Pac J Trop Biomed. 2013; 3(1): 1721. http://dx.doi.org/10.1016/S2221-1691(13)60017-9

39. Bhadauria P, Arora B, Sharma AN, Sing V. A review on Saraca indica plant. . International Resarch Journal of Pharmacy. 2012; 3 (4): 80-4.

40. Mute VM. Anthelmintic effect of Tamarind indica linn leaves juice exract on Pheretima posthuma. Int J Pharma Res and Dev. 2009; 7: 1-6.

41. Roy H. Preliminary phytochemical investigation and anthelmintic activity of Acanthospermum hispidum DC. J Pharma Sci and Tech. 2010; 2 (5): 217-21.

42. Martin RJ. $\gamma$-amino butyric acid and piperazine activated single channel current from Ascaris suum body muscle. Br J Pharmacol. 1985; 84: 44561.http://dx.doi.org/10.1111/j.1476-5381.1985.tb12929.x PMid:2579701 PMCid:1987283

\section{Cite this article as:}

Raihan Khan Tanveer, Karmakar Palash, Das Abhijit, Banik Rana, Sattar Mohammad Mafruhi. Evaluation of cytotoxic and anthelmintic activities of bark extract of Aphanamixis polystachya (Wall.). Int. Res. J. Pharm. 2013; 4(4):126-129 